IJJM

Ilomata International Journal of Management

P-ISSN: 2714-8971; E-ISSN: 2714-8963

\title{
The Effect of Lending and Placement of Funds in Other Banks on the Bank's Ability to Increase Profitability
}

\author{
${ }^{1}$ Eka Febrianti, ${ }^{2}$ Asnah, ${ }^{3}$ Sabri, ${ }^{4}$ Nasfi \\ 1,2,3 Sekolah Tinggi Ilmu Ekonomi Haji Agus Salim, Bukittinggi \\ ${ }^{4}$ STES Manna Wa Salwa, Padang Panjang \\ Corespondent: nasfi.anwar@gmail.com
}

Submitted : September 19,2020 Revised : October 5, 2020 Published : October 30, 2020

\begin{abstract}
This study aims to determine and analyze the effect of lending and placement of funds in other banks on the ability of banks to increase profitability. The study was taken data from one of the XYZ micro banking institutions in West Sumatra, based on year-end financial data from 2009 to 2019. This research uses a quantitative approach. The data source used is secondary data in the form of financial statement data for micro banking institutions for 11 (eleven) years. The data analysis method uses the Ordinary Least Square (OLS) method. The results showed that partially lending had a negative and significant effect on increasing profitability, placement of funds in other banks had a negative and insignificant effect on the increase in profitability of XYZ micro banking. Simultaneously, the variable of credit distribution and placement of funds in other banks has a significant effect on the increase in profitability of the XYZ micro banking institution.
\end{abstract}

Keywords: Credit distribution, placement of funds with other banks and profitability

\section{INTRODUCTION}

The development of Indonesian banking developed quite rapidly before the Covid-19 date, the banking world is currently competing in finding quality customers in order to improve the financial performance of each bank, especially in increasing profitability (Nasfi, 2020a). A bank that can be said to be good if the distribution of loans or loans is balanced with the collection of funds (Antoni, Aimon, H, Nasfi et al., 2019). One measure of the success of a bank is its success in managing loans (credit), considering that the largest placement of bank funds is in the sector of lending (credit), this lending activity is expected to be able to contribute the largest profitability and income to the bank (Arif, Maskur, Sabri, Sabri, Nagara, Patria, Nasfi, 2020).

Law of the Republic of Indonesia Number 10 of 1998 concerning banking says that a bank is defined as a business entity that collects funds from the public in the form of savings and distributes them back to the community in the form of credit to improve people's lives (Nasfi, Iska, et al., 2019). Based on this definition, it can be said that the bank has a role as an intermediary between parties who have excess funds will save their funds in the bank in the form of deposits, while those who need funds will receive funds from the bank in the form of credit(Suandi, Edi, Lukman, Syukri, Primalita, Ratni, Rahim, Rida, Nasfi, 2020).

Among the various bank operational activities, financing services or lending have an important role in the financial sector, through loans extended by banks have motivated people to carry out entrepreneurial activities so that they can increase people's income and reduce unemployment, with the role of banking in the financial sector later having an impact. on improving the Indonesian economy (Antoni, Nasfi, Masri, 2020). 
Loans extended by banks can help people in carrying out their activities, be it consumptive activities or productive activities. Meanwhile, for the bank itself, the credit provided provides benefits in the form of interest earned in return for funds that have been lent to the public. Republic of Indonesia Law No. 7 of 1992 concerning banking as amended by Law No. 10 of 1998 says that the type of bank can be seen from its function consisting of two types of banks, namely, Commercial Banks and Rural Banks (BPR) (Ramadonna et al., 2019).

Law No. 10 of 1998 states that a BPR is a bank that carries out activities conventionally and based on sharia principles which in its activities does not provide services in payment traffic. The BPR business includes, collecting funds from the community in the form of savings, time deposits and other forms to be distributed to the public in the form of credit, providing financing and placement of funds based on the Shari'ah Principles in accordance with the provisions stipulated by Bank Indonesia to place the funds in the form of time deposits, certificates of deposit and savings in other banks (Nasfi, 2020a).

BPR and BMT are a form of microfinance institutions in Indonesia that have roots in the socio-economy of rural communities and have now entered urban communities (Nasfi, Sabri, et al., 2019). According to Law Number 10 of 1998, BPR functions as an intermediary for people with excess funds with people who are short of funds, so the main business carried out by BPR is activities in the credit sector, or channeling funds, so that automatically the largest bank revenue comes from the sector. credit (Nasfi, N, Marta \& Antoni, 2020). The higher the credit, the higher the possibility of a bank getting a profit. By carrying out professional credit management, it is hoped that it can increase bank liquidity and profitability, because high levels of liquidity and profitability indicate high banking performance (Putra, 2013).

The role of BPRs in financing micro and small businesses is still not optimal because the total credit extended by BPRs to MSEs is still low (Maesaroh, 2013). The low level of credit extended is caused by external and internal factors, namely non-current billing, human resources, economic conditions, character and inadequate credit analysis (Jayanti et al., 2018). Another reason why the low credit disbursed by BPRs is the absence of supervision on loans extended and the high interest rate for BPR loans compared to other financial institutions such as commercial banks which are BPR rivals in providing credit to MSMEs (Zulfikar, 2014).

Other external factors that have significantly affected BPR performance are the globalization crisis on the economy and banks, as well as competition between banks which are particularly engaged in microfinance. The most significant effect is the crisis of trust by the public due to the closure of problematic BPR offices, this is very much felt by BPRs with the occurrence of substantial withdrawals of funds in a short time, as well as the reluctance of the public to place their funds in BPRs (Purba et al., 2016).

With the prospect that areas related to the development of MSMEs play a major role in the economy, especially for operational areas, namely rural areas in West Sumatra, especially in alleviating poverty in rural areas(Nasfi, 2020b), where micro banking financial institutions or BPRs prioritize the distribution of funds in the form of credit, who often experience traffic jams and are difficult to resolve or collect. As a researcher, maintaining the image of the micro banking institution under study, the writer will call it the BPR in this study with the initials "XYZ micro banking institution". The development of credit disbursement of the XYZ micro banking financial institution is below; 
The Effect of Lending and Placement of Funds in Other Banks on the Bank's Ability to Increase Profitability Febrianti, Asnah, Sabri, \& Nasfi

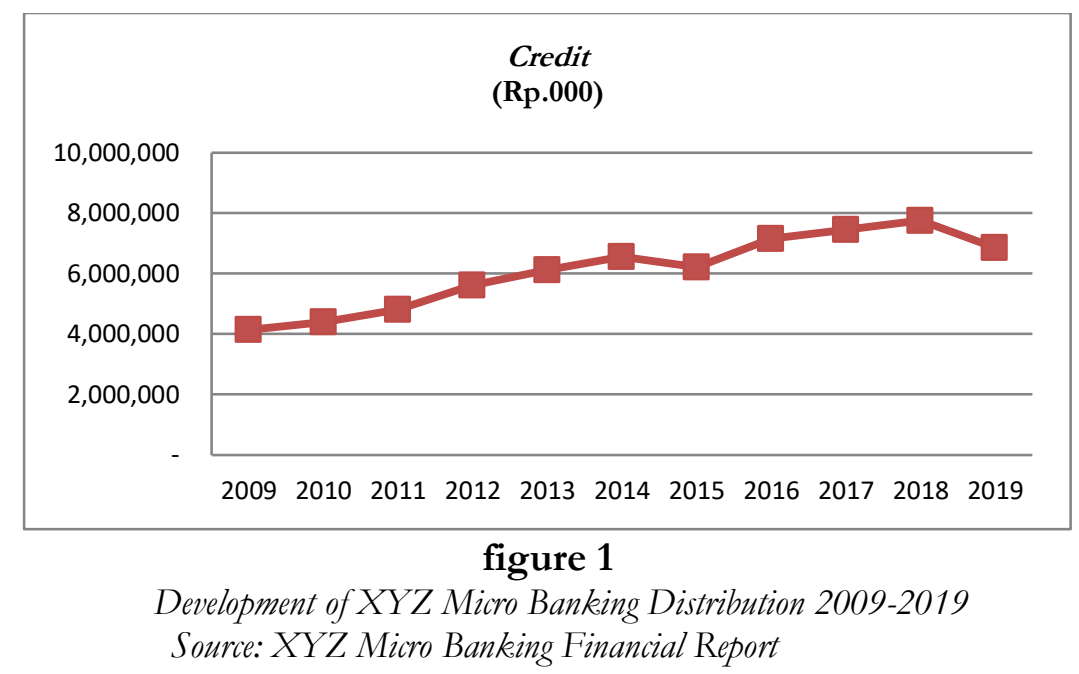

In the graph above, it can be seen that credit disbursement by XYZ micro banking during the last 11 (eleven) years has always fluctuated, based on XYZ micro banking data, the increase in arrears, where the settlement is not maximal which results in a decrease in profitability from credit interest income.

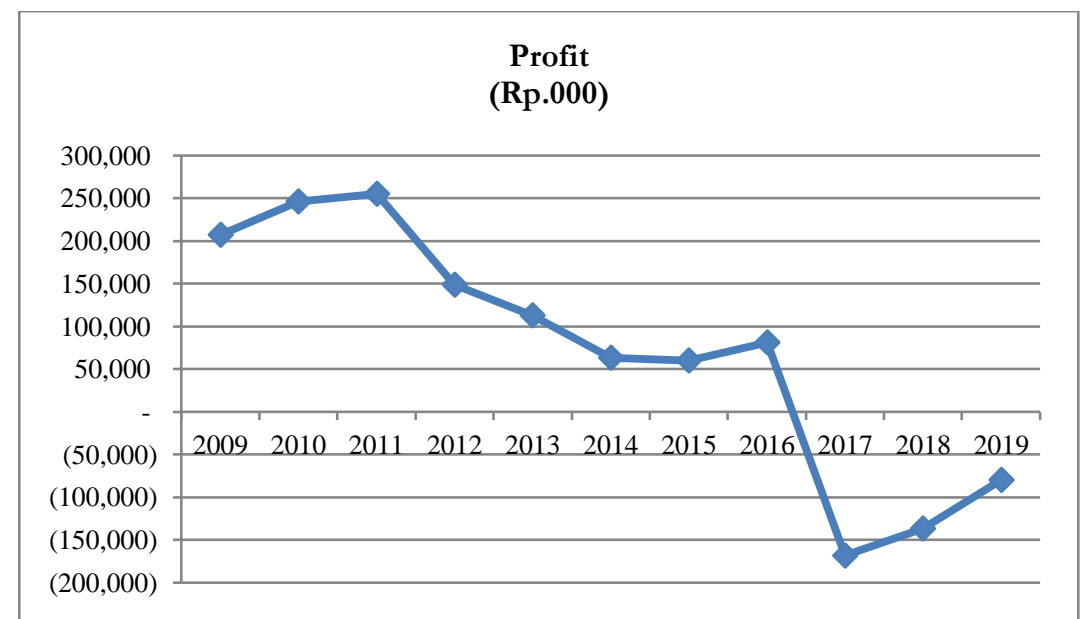

Figure 2

Development of XYZ Micro Banking Profitability 2009-2019 Source: XYZ Micro Banking Financial Report

The financial development of the XYZ micro banking institution from 2009-2019 is illustrated in the graph above, profitability in the form of profits from lending in the last 11 years has fluctuated, XYZ micro banking profits from 2011 to 2017 experienced a significant decline, in 2017 to 2019 it experienced a loss. Profits that continue to decline will have an impact on the health condition of XYZ micro banking and will reduce shareholders' confidence in XYZ micro banking management.

From the published reports of the Financial Services Authority and XYZ micro banking, the last 3 (three) years have seen a decrease in balance sheet items, besides that, not all of the distribution of funds was channeled in the form of productive assets in the form of lending, but more was placed in the interbank asset post. or placements with other banks. Placement of funds with other banks will affect the amount of credit given and will also affect profitability and the level of profits earned. 
Banks are business entities whose activities are to collect funds and channel them back to the public and provide other banking services (Kasmir, 2014), Law No. Article 10 of 1998 concerning banking (1 paragraph 2) states that a Bank is a business entity that collects funds from the public in the form of savings and distributes them to the public in the form of credit or other forms in order to improve the standard of living of the people at large. With many different definitions of a bank, but basically agree to say that banks are business entities whose activities receive savings from the public and channel them back to the public in the form of credit to earn profits and provide services in payment traffic (Andrianto et al., 2019).

Credit is the provision of money or an equivalent bill, based on a loan agreement and agreement between a bank and another party, which requires the borrower to pay off his debt after maturity of course with the provision of interest (Andrianto \& Ak, 2019). Law No. 10 of 1998 says that credit is the provision of money or an equivalent bill based on a loan agreement or agreement between the bank and another party which requires the borrower to carry out the amount of interest in return.

The function of credit is basically the fulfillment of services to serve the needs of society (to seve the society) in the context of encouraging and expediting cultivation, encouraging and expediting production, services and even consumption which are ultimately aimed at increasing the standard of living of many people. While the general function of credit in the trading business world is as follows (Supriyono, 2011):

1. To increase the usability of money. With credit, it can increase the usability of money, meaning that if money is only saved it will not produce anything useful. By giving credit, the money becomes useful for producing goods and services by the recipient of the credit.

2. To increase the circulation and traffic of money. Credit that is distributed will circulate from one area to another, so that an area that is short of money will get additional money through the distribution of credit.

3. To increase the usability of goods. Loans disbursed can be used by debtors to process unused or useless items into useful goods.

4. To increase the circulation of goods. Credit can also increase or facilitate the flow of goods, the amount of goods in circulation from one region to another. By obtaining credit, entrepreneurs can process raw materials into finished goods, so that the usability of these goods increases.

5. As a tool for economic stability. By giving credit, it can be said as economic stability because the credit provided will increase the number of goods needed by the community. And also with lending it can be used as an effort to control inflation, increase exports and fulfill the basic needs of the community.

6. To increase business enthusiasm. For credit recipients, it will certainly increase their enthusiasm for doing business, if the customer is just barely getting enough capital. Everyone who has a business definitely wants their business to increase and develop, but many of them are limited by capital problems.

Profit / Profitability is the company's ability to earn a profit in relation to sales, total assets and own capital (Kasmir, 2015). The level of profitability (bank profit) is largely determined by several factors, such as (Suryani, 2017): (1) providing credit; (2) buying and selling securities; (3) buying and selling foreign currencies; (4) placement of funds in other banks (inter-bank assets); and (5) Provision of services. 
The relationship between the amount of lending and the ability to obtain profitability of $\mathrm{XYZ}$ micro banking institution. Lending is one of the activities of a bank in its business as an institution that is trusted to play a role in driving economic growth. Credit is the main activity of the bank, providing credit is a means to achieve the main goal of the bank, namely making a profit (Andrianto \& Ak, 2019).

The greater the credit extended by the bank, the greater the profit the bank will get. If the bank is unable to distribute credit, while the funds collected from deposits are large, it will cause losses to the bank (Kasmir, 2015). The relationship between the amount of placement of funds or deposits in other banks with the ability to obtain profitability of the XYZ micro banking institution Deposits at other banks are an activity to support the smooth running of operational activities in order to gain profit and serve as a secondary reserve. The greater the deposits in other banks and the greater the interest paid by the bank, the greater the growth of profits that the bank gets(Nasfi, Iska, et al., 2019).

\section{Conceptual Framework}

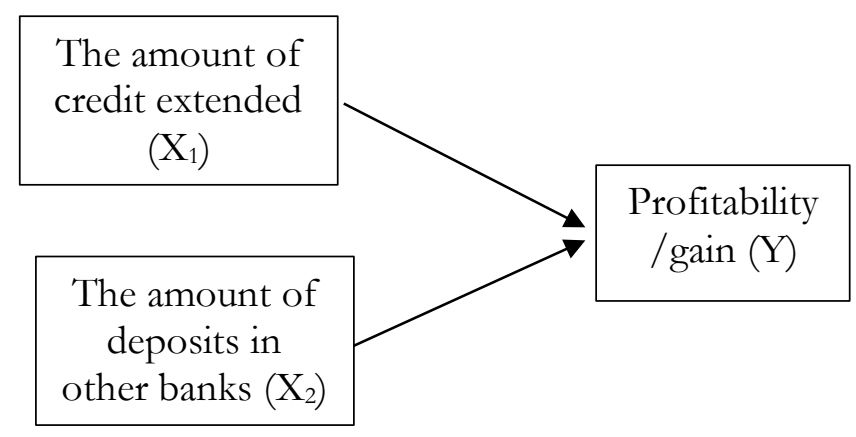

Figure 3

conceptual framework

\section{Hypothesis}

1. Lending or the amount of credit extended $\left(X_{1}\right)$ has a positive and significant effect on profits from the micro banking institution XYZ.

2. Placement of funds with other banks or the amount of deposits in other banks $\left(\mathrm{X}_{2}\right)$ has a positive and significant effect on profitability or profits at XYZ micro banking institution.

\section{METHODS}

In this study, researchers used a quantitative approach. According to (Riyanto \& Hatmawan, 2020) the quantitative approach is an approach that starts from a review of research, processes, hypotheses, descends in the field, analyzes data to conclusions using measuring methods, numerical calculations and using formulas.

Researchers used secondary data obtained from reports from the XYZ micro banking institution. According to (Riyanto \& Hatmawan, 2020) what is meant by secondary data is data collected at a certain time which can describe a situation or activity at a certain time. The data used are time series data from 2009-2019.

The analysis method used to answer the problem / hypothesis is quantitative analysis and to regress the tested variables is the Ordinary Least Square (OLS) method using eviews 9 for windows. Where the Ordinary Least Square (OLS) is to estimate the regression line by minimizing the sum of the squares of the error of each observation against this line (Lohmöller, 2013). 
Regression analysis is basically a study of the dependence of the dependent variable (dependent) with one or more independent variables (independent / explanatory variables), with the aim of estimating and / or predicting the population average or the average value of the dependent variable based on the known value of the independent variable (Cahyanti et al., 2017). The dependent variable $(\mathrm{Y})$ in this study is BPR Profits, while the independent variable is Credit Distribution $\left(\mathrm{X}_{1}\right)$, Deposits at Other Banks $\left(\mathrm{X}_{2}\right)$. Then a model is formed which can be notated functionally as:

$$
\begin{aligned}
& \mathrm{Y}=\mathrm{f}\left(\mathrm{X}_{1}, \mathrm{X}_{2}\right) \ldots \ldots \ldots \ldots \ldots \ldots \ldots \ldots . . . \\
& \text { Where: } \\
& \mathrm{Y}=\mathrm{BPR} \text { profit profitability } \\
& \mathrm{X}_{1}=\text { Credit Distribution } \\
& \mathrm{X}_{2}=\text { Deposits at Other Banks }
\end{aligned}
$$

The function above according to (Gujarati, 2011) can be derived into the regression equation as follows:

$$
\mathrm{Y}=\beta 0+\beta 1 \mathrm{X} 1+\beta 2 \mathrm{X} 2+\mathrm{e} \ldots .
$$

\section{Operational Definition of Variables Dependent Variable (Y)}

The dependent variable is the dependent variable where the amount of the variable depends on the amount of the independent variable (free variable) or it can be said that the variable can be influenced or accepted the consequences of the independent variable. The dependent variable in this study is the profitability of the XXY micro banking institution. The profitability of the XXY micro banking institution is the company's ability to generate profits or profits from assets or sources of income that are trusted to them.

\section{Independent Variable (X)}

Independent variable is a free variable where the magnitude of the variable does not depend on the size of the dependent variable (dependent variable) or a variable whose changes can affect the dependent variable (Lohmöller, 2013). The independent variables in this study are:

1. Lending. Lending is a lending and borrowing activity between banks and borrowers or debtors, where the borrower or debtor is required to pay off the loan at a time agreed by both parties with additional interest.

2. Placement of funds or deposits in other banks. Deposits with other banks are bank obligations to other banks in the form of savings and time deposits.

\section{RESULTS AND DISCUSSION}

Table 1

Multicollinearity Test Results

Coefficient Uncentered Centered

\begin{tabular}{cccc} 
Variable & Variance & VIF & VIF \\
\hline \hline C & $4.38 \mathrm{E}+10$ & 93.96356 & NA \\
CREDIT & 0.000635 & 52.51719 & 1.872499 \\
SBL & 0.000489 & 12.50752 & 1.872499 \\
\hline \hline
\end{tabular}


Table 1 describes the results of the multicollinearity test which shows no multicollinearity, based on the existing provisions that if the VIF value $<10$ then there is no multicollinearity symptom and the values obtained from the calculation are 1.87, which means they are smaller than 10 and from the results of the analysis above it can be seen multicollinearity does not occur in the variable credit and deposits at other banks so that the model has met the requirements of the classical assumptions in the regression analysis.

Table 2

Heteroscedasticity Test

Heteroskedasticity Test: Glejser

\begin{tabular}{llll}
\hline \hline F-statistic & 0.521790 & Prob. F(2,8) & 0.6123 \\
Obs*R-squared & 1.269341 & Prob. Chi-Square(2) & 0.5301 \\
Scaled explained SS & 0.940901 & Prob. Chi-Square(2) & 0.6247 \\
\hline \hline
\end{tabular}

Table 2 describes the results of the heteroscedasticity test which shows that the probability value of the F-count based on the results of the heteroscedasticity test shows the number 0.61 which means the large of the alpha level is 0.05 and the calculated Chi-Square Probability of all tests shows a number of 0.53 which means greater than the alpha level of 0.05 , the value of the probability F-count and the Chi-Square Probability of the alpha level of 0.05, it can be concluded that there is no heteroscedasticity in the model.

Table 3

Autocorrelation Test

Breusch-Godfrey Serial Correlation LM Test:

\begin{tabular}{llll}
\hline \hline F-statistic & 0.092823 & Prob. F(2,6) & 0.9126 \\
Obs*R-squared & 0.330138 & Prob. Chi-Square(2) & 0.8478
\end{tabular}

Table 3 illustrates that based on the results of the autocorrelation test above the Prob value. F is $0.91>0.05$ and the Prob value. Chi-Square is $0.84>0.05$, it can be concluded that there is no autocorrelation, which means that the proposed linear regression model does not contain autocorrelation.

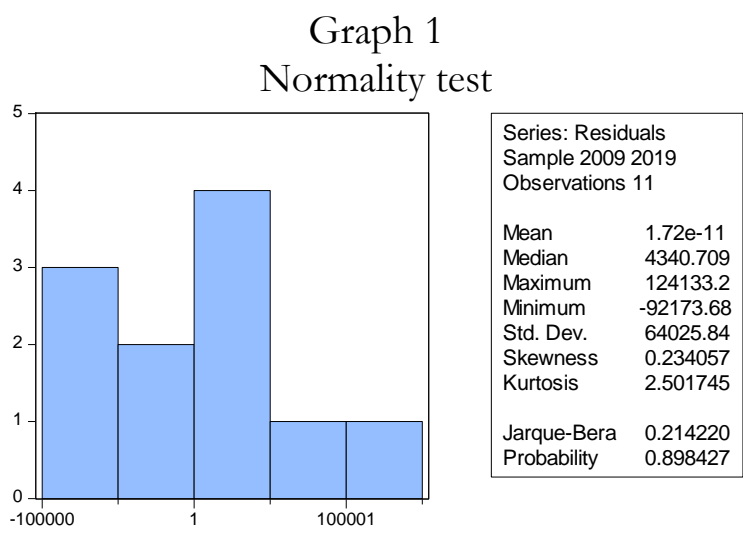

Graph 1 illustrates the results of the normality test which is based on the graph above the Jarque-Bera Probability value of $0.89>0.05$, it can be concluded that the data is normally distributed, which means that the classical assumptions about normality have been fulfilled. 
Based on the results of the four stages of the classical assumption test, the data is suitable for use because the data passes the four test stages because there is no storage in the classical assumption test stage, besides that all models are said to be quite good and can be used for research.

The $t$ test was conducted to see the effect of the independent variable individually (partially) on the dependent variable. This test is done by comparing the results of the t-count with the existing t-table. If t-count $>\mathrm{t}$-table, it can be stated that this variable has a significant effect on the dependent variable.

1) Testing of credit extended

The $\mathrm{t}$-count value for extended credit is -4.46 while the $\mathrm{t}$-table value is -2.44 because $-\mathrm{t}$ count $>$ - $t$ table, Ho is rejected, this means that the channeled credit variable has a negative and significant effect on profitability or profitability at XYZ micro banking institutions .

2) Testing of deposits at other banks

The $t$ value for deposits in other banks is -0.32 while the $t$-table value is -2.44 . Because of $-t$ count $<$-t table, Ho is accepted, this means that the savings variable at other banks does not have a significant effect on the profitability of XYZ micro banking institutions.

Based on the results of the F-count test, it is obtained that the F-count value is 16.88 with a significant level of 0.0013 , when compared with the F-table at $80 \%$ confidence (significant $5 \%$ or $0.05)$ is 5.14 then F-count $>$ F-table $(16.88>5.14)$, it can be concluded that together the variables of credit extended and deposits at other banks have a significant effect on profitability.

Based on the regression results of the effect of the independent variable, namely loans extended and deposits at other banks on profit, an R-squared value of 0.80 is obtained, which means that about $80 \%$ of profits are influenced by the variables extended credit and deposits at other banks, while the remaining $20 \%$ is explained. factors that are not included in this research model, so that the $\mathrm{R} 2$ of 0.80 is stated that the model is valid.

Based on the formation of models and multiple regression equations, the test results are as follows:

$$
\begin{aligned}
& \mathrm{Y}=7794-0.112 \text { Kredit }-0.007 \mathrm{SBL}+\mathrm{e} \\
& \mathrm{t} \text {-test }=\quad(-4.46) \\
& \text { Prob }=(0.0058)(0.0021)
\end{aligned}
$$

From the regression results above it is known that:

1. The effect of channeled creditors $\left(\mathrm{X}_{1}\right)$ on the acquisition of profitability $(\mathrm{Y})$

The variable of credit extended has a negative and significant effect on profitability. This can be seen from the credit coefficient value of -0.112 percent and the probability value of 0.0021 . This means, if the credit extended increases by 1 percent, the profit will decrease by 0.112 percent, assuming cateris paribus.

This is not in line with the theory that the amount of credit extended will determine the bank's profit (Sari, 2013), this is not in line with previous research conducted by (Mahardika et al., 2014) the case study of the Village Credit Institution (LPD). who found that loans had a positive and significant effect on LPD profits. So it can be concluded that the greater the credit extended, the greater the profits will be obtained.

Loans disbursed have a negative and significant effect on profitability. This is due to the large number of non-performing loans that have decreased the profits earned by XYZ microfinance institutions.

2. Effect of deposits in other banks $\left(\mathrm{X}_{2}\right)$ on profit $(\mathrm{Y})$ 
Deposits at other banks have a negative and insignificant effect on profitability. This can be seen from the coefficient value of deposits in other banks of -0.007 with a probability value of 0.7559 .

Thus, if lending will have an impact on the probability of a bank in practice, the loan portfolio will increase with the debtor's return rate as current and the selling price (interest) of credit above the Base Landing Rate (BLR) or above the basic interest rate for lending, this opinion is in accordance with practitioners. Nasfi micro banking senior where the volume of credit increases with a record of credit repayments are classified as smooth from the debtor.

Likewise, the placement of earning assets or funding does not have a major effect on bank profitability, where interest in the form of interbank income on these assets is relatively small and usually in banking practice is mostly used to safeguard liquidity in Nasfi's opinion.

\section{CONCLUSION}

Partially disbursed loans have a negative and significant effect on profit gains, while deposits at other banks have a negative and insignificant effect on profitability of XYZ micro banking institutions.

Simultaneously, the variable extended credit and deposits at other banks has no significant effect on the profitability of the XYZ micro banking institution.

The R2 test result is 0.80 , which indicates that $80 \%$ of $\mathrm{XYZ}$ micro banking institution profitability is influenced by the variable of credit extended and deposits at other banks, while the remaining $20 \%$ is explained by factors not included in this research model.

\section{REFERENCES}

Andrianto, S. E., \& Ak, M. (2019). MANAJEMEN KREDIT (Teori dan Konsep Bagi Bank Umum). Penerbit Qiara Media.

Andrianto, S. E., Ak, M., Didin Fatihuddin, M. M., Firmansyah, M. A., \& SE, M. M. (2019). Manajemen Bank. CV. Penerbit Qiara Media.

Antoni, Aimon, H, Nasfi, N., Ramadonna, Y., \& Subhan, M. (2019). The Effect of Internal and External Factors on Bank Investment Credit's Demands (Kesan Faktor Dalaman dan Luaran ke atas Permintaan Pelaburan Kredit Perbankan). Jurnal Ekonomi Malaysia, 53, 2. https://doi.org/http://dx.doi.org/10.17576/JEM-2019-5302-18

Antoni, Nasfi, Masri, R. (2020). The Role of Construction and Financial Sectors for Economic Growth in Indonesia. International Journal of Innovation, Creativity and Change, 12(2).

Arif, Maskur, Sabri, Sabri, Nagara, Patria, Nasfi, N. (2020). SWOT Analisis dan Matrik SWOT Analisis Dalam Rangka Pemasaran Produk Pendanaan Bank (Studi PT. BPR Rangkiang Aur). Jurnal Point Equilibrium Manajenem \& Akuntansi Volume, 2(1).

Cahyanti, D. A., Nuraina, E., \& Wijaya, A. L. (2017). Pengaruh Likuiditas, Profitabilitas, dan Leverage Terhadap Arus Kas Masa Mendatang Pada Perusahaan Properti dan Real Estate di BEI. Assets: Jurnal Akuntansi Dan Pendidikan, 6(1), 26-41.

Gujarati, D. N. (2011). Basic econometrics. Tata McGraw-Hill Education.

Jayanti, L. D., Alfansi, L., \& Anggarawati, S. (2018). Analisis Pelaksanaan Pemberian Kredit pada PT. BPR Dian Binarta Arga Makmur Bengkulu Utara. The Manager Review Jurnal Ilmiah Manajemen, 15(4), 642-683.

Julia, T. T., \& Diyani, L. A. (2015). Pengaruh Faktor Fundamental Keuangan dan Makroekonomi terhadap Harga Saham. Jurnal Bisnis Dan Komunikasi Kalbisocio, 2(2). 
The Effect of Lending and Placement of Funds in Other Banks on the Bank's Ability to Increase Profitability

Febrianti, Asnah, Sabri, \& Nasfi

Kasmir. (2014). Bank dan Lembaga Kenangan Lainnya. Penerbit PT Raja Grafindo.

Kasmir, D. (2015). Dasar-Dasar Perbankan Edisi Revisi 2014. Jakarta: Rajawaloi Pers.

Lohmöller, J.-B. (2013). Latent variable path modeling with partial least squares. Springer Science \& Business Media.

Maesaroh, S. (2013). Peranan bank perkreditan rakyat (BPR) dalam meningkatkan keberhasilan sektor UMKM. Sustainable Competitive Advantage (SCA), 2(1).

Mahardika, I. M. A., Cipta, W., \& Yudiaatmaja, F. (2014). PENGARUH KREDIT BERMASALAH DAN PENYALURAN KREDIT TERHADAP LABA PADA LEMBAGA PERKREDITAN DESA (LPD). Jurnal Manajemen Indonesia, 2(1).

Mokosolang, C., Prang, J., \& Mananohas, M. (2015). Analisis Heteroskedastisitas Pada Data Cross Section dengan White Heteroscedasticity Test dan Weighted Least Squares. D'CARTESIAN, 4(2), 172-179.

Nasfi, N, Marta, Y., \& Antoni, A. (2020). Analisis Tingkat Kesehatan Bank Sebelum Dan Sesudah Merger Di Sumatera Barat (Studi Kasus: PT. BPR Rangkiang Aur dengan PT. BPR Rangkiang Denai). Jurnal Menara Ekonomi: Penelitian Dan Kajian Ilmiah Bidang Ekonomi, 6(1). https://doi.org/https://doi.org/10.31869/me.v6i1.1748

Nasfi, N. (2020a). Analisis Kenerja Keuangan Bank Pembiayaan Rakyat Syariah (BPRS) Sumaatera Barat. Tamwil, 5(2), 131-150. https://doi.org/http://dx.doi.org/10.31958/jtm.v5i2

Nasfi, N. (2020b). Pengembangan Ekonomi Pedesaan Dalam Rangka Mengentas Kemiskinan di Pedesaan. Jurnal EL-RIYASAH, 11(1), 54-66. https://doi.org/http://dx.doi.org/10.24014/jel.v11i1.8818

Nasfi, N., Iska, S., Nofrivul, N., \& Antoni, A. (2019). Financial Sustainability In The Assessent of The Financial Pemormance of West Sumatera Sharia Financing Bank (BPRS). Jurnal Menara Ekonomi: Penelitian Dan Kajian Ilmiah Bidang Ekonomi, 5(1).

Nasfi, N., Sabri, S., \& Moni, R. (2019). Prosedur Pemberian dan Penyelesaian Pembiayaan Bermasalah di KJKS BMT Agam Madani Nagari Batu Palano Kabupaten Agam. JUSIE Jurnal Sosial Dan Ilmu Ekonomi), 4(02), 98-107. https://doi.org/https://doi.org/10.36665/jusie.v4i02

Purba, N. N., Syaukat, Y., \& Maulana, T. N. A. (2016). Faktor-Faktor Yang Memengaruhi tingkat Penyaluran kredit Pada BPR konvensional di Indonesia. Jurnal Aplikasi Bisnis Dan Manajemen (JABM), 2(2), 105.

Putra, A. F. (2013). Pengarub LDR, IPR, APB, NPL, IRR, PDN, BOPO, FBIR dan FACR Terbadap Return On Asset (ROA) Pada Bank Pembangunan Daerah Di Indonesia. STIE PERBANAS SURABAYA.

Ramadonna, Y., Nasfi, N., \& Aziz, Z. (2019). The Effect Of Customer Relationship Management And Customer Value On Customer Satifsfaction Of Service And Its Impact on Customer Loyality In PT. BPR Rangkiang Aur. Jurnal Menara Ekonomi: Penelitian Dan Kajian Ilmiah Bidang Ekonomi, 5(1). https://doi.org/https://doi.org/10.31869/me.v5i1.1277

Riyanto, S., \& Hatmawan, A. A. (2020). Metode Riset Penelitian Kuantitatif Penelitian Di Bidang Manajemen, Teknik, Pendidikan Dan Eksperimen. Deepublish.

Sari, G. N. (2013). Faktor-Faktor Yang Mempengaruhi Penyaluran Kredit Bank Umum Di Indonesia (Periode 2008.1-2012.2). Jurnal EMBA:Jurnal Riset Ekonomi, Manajemen, Bisnis Dan Akuntansi, 1(3). 
The Effect of Lending and Placement of Funds in Other Banks on the Bank's Ability to Increase Profitability

Febrianti, Asnah, Sabri, \& Nasfi

Sofyan, M. (2019). ANALYSIS FINANCIAL PERFORMANCE OF RURAL BANKS IN

INDONESIA. International Journal of Economics, Business and Accounting Research (IJEBAR), 3(3), 255-262. doi:10.29040/ijebar.v3i03.588

Suandi, Edi, Lukman, Syukri, Primalita, Ratni, Rahim, Rida, Nasfi, N. (2020). Relationship Between Blue Ocean Strategy, Customer, And Islamic Bank Performence. Jurnal Ipteks Terapan, 14(2). https://doi.org/http://doi.org/10.22216/jit.2020.v14i2.5319

Supriyono, M. (2011). Buku pintar perbankan. Penerbit Andi.

Suryani, T. (2017). Manajemen Pemasaran Strategik Bank Di Era Global. Prenada Media.

Zulfikar, T. (2014). Pengaruh CAR, LDR, NPL, BOPO dan NIM Terhadap Kinerja Profitabilitas (ROA) Bank Perkreditan Rakyat Di Indonesia. E-Journal Graduate Unpar, 1(2), 131-140. 